\title{
Nas alamedas da memória: acerca da condição do poeta no imediato pós-Guerra Civil Espanhola
}

\author{
Through the promenade of memory: on the poet's condition right after the Spanish Civil War
}

\author{
Mayra Moreyra Carvalho
}

Universidade de São Paulo - São Paulo - Brasil

$\diamond$

\begin{abstract}
Resumo: O artigo apresenta uma leitura do conjunto de poemas de Rafael Alberti "De los álamos y los sauces", que integra a obra Entre el clavel y la espada. Compostos em 1940, primeiro dos mais de trinta anos de exílio de Alberti na Argentina, os poemas dedicados a Antonio Machado, morto dias após o fim da Guerra Civil Espanhola, mobilizam referências que sustentam o imaginário da literatura ocidental, permitindo pensar como se figura liricamente a condição do poeta num momento histórico tão próximo ao conflito. A partir da aproximação com a representação iconográfica da melancolia sugerida pela postura inclinada do sujeito lírico, nosso percurso analítico se centra nos momentos do choro e da reflexão, nos quais o poeta problematiza sua relação com a natureza, enfrenta-se com a crise da representação diante da barbárie e elabora aquele que será o compromisso ético e estético de sua poesia futura: a recusa do esquecimento.
\end{abstract}

Palavras-chave: Poesia; Memória; Guerra Civil Espanhola; Melancolia

\begin{abstract}
This paper presents an analysis of Rafael Alberti's "De los álamos y los sauces", a set of poems in his book Entre el clavel y la espada. Written in 1940, the first of more than thirty years Alberti lived as an exiled in Argentina, the poems dedicated to Antonio Machado, dead right after the end of the Spanish Civil War, collect some references that support Western literature, which allows us to think on how the poet's condition in that moment of History is lyrically transfigured. Once the bent position of the lyric-self suggests an approach to the pictorial representation of melancholy, our analysis focuses on its two moments: crying and reflection, throughout which the poet questions his relation to nature, faces the crisis of representation and creates what will be his poetry ethical and aesthetic commitment: he refuses oblivion.
\end{abstract}

Abstract: Poetry; Memory; Spanish Civil War; Melancholy

Rafael Alberti caminha por uma avenida bordeada por álamos em uma pequena localidade no interior da Argentina. Assaltam-no simultaneamente a familiaridade que essas árvores representam, também elas abundantes em sua terra natal, e o estranhamento, ao olhar o céu para o qual os álamos apontam e não encontrar a constelação da Ursa Maior. Os álamos, costumeiramente respondendo à passagem do vento, reavivam a memória, que afaga, porque envolve o poeta num cenário conhecido e acolhedor; mas açoita, porque confirma a condição de exílio. Tendo consigo só a memória, o poeta parece tentar fixá-la: talha no tronco de um álamo um nome para aquela avenida (antípoda de tudo o que é seu): Alameda Antonio Machado.

Este episódio foi narrado pelo poeta espanhol Rafael Alberti (1902-1999) em 08 de março de 1987 na coluna que escrevia para o jornal El País, cujos textos depois se incorporaram à sua autobiografia La Arboleda Perdida. No momento da escritura, Alberti já havia retornado à Espanha, depois de um longo exílio de quase quarenta anos. O episódio rememorado ocorreu em algum momento entre 1940 e 1944, anos em que viveu em Villa del Totoral, na província de Córdoba, Argentina. Esta foi sua primeira residência na América, emprestada pelo companheiro de Partido Comunista Rodolfo Araóz Alfaro.

Entre a escritura do texto e o acontecimento há uma distância temporal considerável, e quiçá - ou provavelmente - uma dose da imaginação poética de Rafael Alberti. Pouco importa, no entanto, se efetivamente o poeta talhou em uma árvore o nome com o qual batizou aquela alameda ou se, de fato, "ainda sabe", após mais de quarenta anos, o número e a disposição espacial dos 
álamos como insiste em declarar no texto. Importanos que ele tenha escolhido contar dessa maneira sua experiência na pequena cidade argentina, que tenha apresentado aquele lugar como uma sobreposição de lembranças e como um espaço de fixação da memória. Dizemos sobreposição, porque Alberti relata no texto a lembrança de uma lembrança: ele se lembra de passear pela alameda, o que evoca a figura de Antonio Machado, este também um poeta que plasmou em versos suas caminhadas por entre os álamos de Sória, região centronorte da Espanha. Ademais, trata-se de um espaço de fixação da memória quando consideramos o caráter simbólico da escrita no tronco de uma árvore. Com o gesto, Alberti nomeia a alameda, portanto, torna próprio algo que the era alheio "para que al menos en el recuerdo de ésta quedase memoria de los pasos y sentimientos de un español errante" (ALBERTI, 2009, p.326). O gesto tem ainda ele próprio uma memória, no sentido de que atualiza uma prática comum e cuja gênese se perde no tempo. Fazê-lo é também repeti-lo; replicar a tentativa de fixar na cortiça de uma árvore um tempo, um espaço, um nome que identifica, da mesma maneira como fizeram os personagens de Antonio Machado no poema VIII de Campos de Castilla: "Estos chopos [...]/tienen en sus cortezas/grabadas iniciales que son nombres/de enamorados, cifras que son fechas" (2012, p. 142).

Esse arranjo da narrativa albertiana de 1987, apresentada como um trabalho da memória que privilegia o recontar de uma cadeia associativa, é revelador da maneira como o próprio poeta entende - ou busca entender - o passado seu a que se refere. Aquele tempo correspondia aos primeiros anos do exílio de Rafael Alberti. Visto a partir do agora da enunciação, figura como o momento do sujeito ainda desorientado, para quem os elementos da natureza tornam-se os pontos de referência. No entanto, eles aturdem, pois são concretamente o nãoestar na Espanha. À desorientação do exílio recente, o poeta respondeu aferrando-se ao que aquele novo espaço precipitava em sua memória. Nesse sentido, Antonio Machado aparece em virtude da associação entre álamos argentinos e espanhóis. Mas a aparição é signo de uma condição mais complexa, um tecido de relações que configurará o compromisso assumido por Rafael Alberti desde o início do exílio e buscado em toda sua obra: a recusa do esquecimento.

No entanto, essa leitura da própria trajetória só pode ser feita com lucidez pelo poeta em 1987 devido à distância temporal, os mais de quarenta anos durante os quais aquelas experiências já decantaram e são passíveis de interpretação. No imediato pós-Guerra Civil Espanhola, cujos desdobramentos obrigaram Rafael Alberti ao exílio, encontramos outra reação: o primeiro livro escrito pelo poeta na América, Entre el clavel y la espada, publicado em maio de 1941 em Buenos Aires. Justamente em Villa del Totoral, em junho de 1940, ele compõe a quinta seção da obra: "De los álamos y los sauces, En recuerdo de Antonio Machado", um conjunto de poemas que nos instiga a pensar de que maneira o poeta estabelece e desenvolve a tríade relacional Antonio Machado-álamos-memória naquele primeiro momento de seu exílio. Buscaremos refletir sobre como ele trabalha a relação entre esses elementos naquele período tão próximo dos acontecimentos da Guerra Civil Espanhola e que efeito isso cria.

\section{Um percurso entre álamos e sauces}

O conjunto de poemas "De los álamos y los sauces" é publicado na Argentina em 28 de outubro de 1940, antes do livro que futuramente integrará, Entre el clavel y la espada. Tem uma tiragem limitada, com exemplares numerados, sendo os 120 primeiros assinados pelo poeta ${ }^{1}$. Os dados presentes no colofão do livro permitem-nos afirmar que se trata de uma edição especial. Primeiro porque é produzida por Francisco A. Colombo, editor que introduz os paradigmas das publicações esmeradas na Argentina, a partir de 1920 (qualidade do papel, ilustrações e disposição do texto). O selo editorial Ángel Gulab é outra evidencia do caráter desta publicação, pois foi criado em 1938 por Daniel Devoto, crítico literário, poeta e musicista, para possibilitar a impressão de edições especiais. Por fim, há duas gravuras feitas exclusivamente para a obra por Eduardo Catalano, à época recémgraduado e que viria a ser um importante arquiteto no cenário mundial no século XX.

Todas essas informações são relevantes na medida em que demonstram que Rafael Alberti se insere em uma rede cultural já no primeiro ano de sua chegada na Argentina. Ao contrário do que a condição de exílio poderia fazer supor - um estrangeiro recém-chegado, e por isso apartado dos círculos artísticos do novo país - a presença do poeta é notada e sua voz reverbera, o que não é pouco quando lembramos que se trata de uma figura cujas posições políticas são claras e a poesia não é menos contundente.

Os elementos iniciais que encontramos depois do título são duas epígrafes. A primeira é da Fábula de Genil, de Pedro Espinosa (1578-1650): "Paró el agua a su queja, y por oílla/Los sauces se inclinaron a la orilla". Trata-se de uma composição em versos que narra a origem do rio Genil à maneira da tradição ovidiana das Metamorfoses. Na passagem escolhida por Alberti, o deus Genil chega

\footnotetext{
Tivemos a oportunidade de consultar três exemplares de "De los álamos y los sauces": na Biblioteca Nacional de España, na Fundación Rafael Alberti e no Centro de la Generación del 27, neste último, um dos exemplares assinados pelo poeta.
} 
à margem de um rio tocando com dedos habilidosos a cítara para cantar sua dor de amante desprezado pela ninfa Cinaris. Os elementos da natureza ao redor se compadecem do canto e se tornam testemunhas da pena do deus.

A segunda epígrafe é de Antonio Machado, os dois versos finais do poema VIII de "Campos de Soria", que faz parte da obra Campos de Castilla (1907-1917): “... álamos de las márgenes del Duero,/ conmigo vais, mi corazón os lleva!". Em linhas gerais, observa-se no poema de Machado uma integração do cenário natural com o sujeito, uma vez que é possível que ele o leve consigo, num movimento de recordação que é bem-sucedido, e que, neste sentido, perfaz o que Paul Ricoeur chamaria de "memória "feliz" (2007, p. 54).

Esses versos de Espinosa e Machado mobilizam uma série de motivos que serão os princípios norteadores de nossa leitura dos poemas albertianos: o canto do poeta, o papel da natureza e a memória.

\subsection{O melancólico que chora}

No primeiro poema de "De los álamos y los sauces", reclama-se a possibilidade de viver algo à exaustão. Querse ter o direito ao pranto, uma necessidade tamanha que a vemos expressada de maneira hiperbólica: "Dejadme llorar a mares,/ largamente como los sauces.//Largamente $y$ sin consuelo./Podéis doleros.../Pero dejadme." (ALBERTI, 2003, p. 369).

Os versos de ritmo arrastado, efeito sonoramente criado pela repetição da vogal aberta /a/, ecoam a composição do século XVI em que Luís de Góngora recria uma cantiga medieval, dando voz ao lamento da mulher que chora a morte do marido na guerra: "Dejadme llorar/orillas del mar" (2010, p.151). Ao direito ao pranto, o sujeito adiciona sua vontade de poder retirar-se do convívio para chorar em solidão, reivindicação que o significado do verbo e o modo imperativo reforçam: "Dejadme".

A imagem em torno da qual se organiza a figuração que temos desse sujeito lírico é o sauce, em português chamado salgueiro ou, significativamente, chorão. É uma árvore de grande porte, que cresce comumente à margem de rios, inclinando-se em direção a eles. Como descreve Herrero Uceda, "El porte de este árbol es inconfundible: las numerosas ramas, finas, flexibles y largas, cuelgan desde la copa hasta alcanzar al suelo" (2005, p. 77). Devido à sua morfologia, o sauce aparece no imaginário ocidental, inclusive na literatura, como evocação do sentimento de tristeza ou associado à morte (CHEVALIER, 1986, p.916).

A relação de similaridade que o eu-lírico estabelece com os sauces permite-nos reconhecer nele uma posição consagrada na iconografia do ocidente a partir dos séculos XVI e XVII: inclinado, ensimesmado, ele é o melancólico. No século XX, a melancolia foi investigada esteticamente por críticos como Walter Benjamin (1984), Paul Ricoeur (2007) e Jean Starobinski (2014). Do ponto de vista estético, Ricoeur estabelece a gravura de Albert Dürer, Melencolia I, de 1514, como paradigma da representação da melancolia pelas artes visuais e a descreve nos seguintes termos: "Uma mulher está sentada, o olhar mergulhado numa distância vazia, o rosto obscuro, o queixo apoiado num punho cerrado; [...]. A melancolia é para sempre essa figura inclinada, pensativa" (2007, p. 89). Benjamin também observa esse "olhar voltado para o chão" que caracteriza o melancólico, a quem ele chama de "saturnino"2 (1984, p. 175). Em Starobinski, é justamente a partir do "motivo da figura inclinada" que se discute a melancolia na poesia de Charles Baudelaire (2014, p. 12).

Essa postura do melancólico tem para os três críticos duas possibilidades de interpretação que não se excluem: ela é tanto o signo da tristeza quanto o do sujeito que pensa. Na bela formulação de Starobinski, trata-se tanto da "tristeza estéril" como da "meditação fecunda", da "prostração do vazio" como da "plenitude do saber" (2014, p. 45). O eu-lírico inclinado do primeiro poema de "De los álamos y los sauces" parece estar tomado somente pelo primeiro sentimento, pois o vemos inconsolável. No entanto, o próprio movimento de escritura, que não é aparente, mas condição tácita para a existência do poema, indicia que há um pendor reflexivo.

No segundo poema, a terceira estrofe reitera a postura inclinada do sujeito lírico, reforçando sua representação como melancólico: "Álamo, me pesas mucho;/me doblas los hombros sauce" (ALBERTI, 2003, p. 370). Por que as árvores lhe pesariam sobre os ombros? Quem é este que se dirige aos álamos e sauces? Nas demais estrofes do poema, este sujeito não falava em primeira pessoa. Nelas, encontra-se um sujeito indefinido que é pequeno diante das árvores grandes, e que tem por companheira apenas a yerbabuena, a hortelã. $\mathrm{Na}$ última estrofe, este sujeito indefinido senta-se e, a despeito de ser rio, não pode contar com a ajuda da água. Ora, essa situação remete-nos aos versos da Fábula de Pedro Espinosa que epigrafam o conjunto, nos quais o deus, que futuramente seria um rio, comovia a natureza com seu canto doloroso. Em Alberti, o elemento natural se mostra indiferente à debilidade do sujeito, não o ajuda, e, ao contrário, exacerba seu sentimento de fraqueza.

\footnotetext{
2 Entende-se que o humor melancólico é governado por Saturno, o astro de órbita mais longa. Sua influência justificaria a lentidão, o alheamento e o ensimesmamento dos melancólicos (BENJAMIN, 1984, p.171; SONTAG, 1986, p. 88)
} 
É possível aproximar este eu-lírico a uma figuração do poeta, pois, além de encenar as relações entre a natureza e o sujeito, este aparece identificado a um rio - maneira como Alberti apresenta muitas vezes Antonio Machado ${ }^{3}$. É oportuno lembrar que na tradição literária o poeta paradigmático é Orfeu. Filho de Calíope, musa da poesia épica, e Apolo, deus que porta a lira, Orfeu representa "com bastante propriedade um modelo, de certa forma ideal, de artista, de poeta e de músico" (CARMO NETO, 2009, p. 70). Esses atributos advêm do repertório narrativo da mitologia greco-romana, principalmente da maneira como é representado no Livro X das Metamorfoses de Ovídio. As passagens do choro de Orfeu à margem de um rio e do catálogo de árvores que se compadecem dele tornam-se muito significativas na história da literatura, pois, o poeta passa a ser identificado como aquele que pode arrebatar os elementos da natureza com seu canto. Ele tem uma capacidade encantatória, "um poder ativo sobre a natureza" (HADOT, 2006, p. 207) ${ }^{4}$. Esse atributo órfico será lugar comum, por exemplo, na poesia de Petrarca e em toda a tradição que o segue, como é o caso de Pedro Espinosa, e do também espanhol Garcilaso de la Vega, em cujo "Soneto XV" as "quejas y lamentos pueden tanto/que enfrenaron el curso de los ríos/y en los diversos montes y sombrios/los árboles movieron con su canto" (1995, p. 37).

É justamente esta capacidade órfica do poeta que se apresenta como uma impossibilidade no segundo poema de "De los álamos y los sauces". Nele, a natureza se contrapõe ao poeta, e, desde sua perspectiva, não demonstra solidariedade em relação a sua dor. A única planta com que o poeta se identifica, a hortelã, é rasteira, e a força que possui está em algo volátil e invisível, o aroma. Os álamos e sauces atestam a condição de debilidade do poeta, pois sua ancestralidade e significado pesam-lhe aos ombros na medida em que contrastam com a impossibilidade que ele enfrenta de simbolizar a dor. $\mathrm{O}$ poeta condenado ao sofrimento presente - um sofrimento que já não decorre do lamento amoroso, mas da guerra $\mathrm{e}$ do exílio - tenta ativar uma memória da tradição literária, que se revela insuficiente.

Em resposta ao cenário negativo dominante no segundo poema, o terceiro se apresenta como tentativa de contraponto. A conjunção aunque, que anteriormente havia sido explorada em seu viés adversativo, reaparece como força motriz de uma concessão: " $Y$ cantaré más alto, aunque esta tierra ni me escuche y hable" (ALBERTI, 2003, p. 371). A despeito da disposição "contra-órfica" da

\footnotetext{
3 Na "Canción 16" da obra Baladas y canciones del Paraná (1953), Machado é "Un río que no se mueve,/pero que nos da la mano" (ALBERTI, 2006, p. 517).

4 Tradução minha para “[...] Orpheus, whose song has an active power over nature".
}

natureza, o eu-lírico anuncia sua convicção, materializada linguisticamente pelo futuro do presente. Daquela posição inclinada em que se encontrava, o sujeito parece agora recobrar altivez, há um desejo de querer erigir-se. No entanto, a confiança enunciada nas estrofes de abertura do poema mostra sinais de oscilação a partir da terceira, pois o sujeito é tomado pela dúvida, manifestada pelas perguntas essenciais: "quem?”, "para onde?”: “De quién es esa voz, /esas ramas que pasan sin pararse?// De los álamos tienen/el tiemblo, y el silbido de los sauces.//_Adónde irán, perdidas,/cantando, ciegas, sin mirar a nadie?" (ALBERTI, 2003, p. 371).

Verifica-se uma mudança do singular (esa voz) para o plural (pasan, tienen, irán) que se conforma como um índice de oscilação, pois a identidade da voz passa do sujeito para os elementos vegetais, os ramos dos álamos. Essa transmutação não deixa de ser também signo de um apequenamento do poeta, reduzido a sua voz. Por outro lado, a voz que se apresenta é cega, o que remete imediatamente a outra clássica representação do poeta: o aedo, o cantor que prescinde da visão porque é dotado do dom das musas para a memória e a poesia.

Tudo isso que o poema mobiliza revela um eulírico vacilante, portador de uma voz poética poderosa, mas inseguro quanto ao destino dessa mesma voz. Essa disposição de incerteza que organiza o poema se mantém nos versos finais: "Van a la mar, al mar. Si no volvieran, les que quieren quedarse" (ALBERTI, 2003, p.371). A resposta sobre o destino da voz - o além-mar - traz para a composição a carga histórica da experiência que Rafael Alberti vive naquele momento. O exilado deseja que o canto ultrapasse os espaços para chegar, talvez, à Espanha. Se a voz não voltar, significa que quis ficar. A conclusão pode ser lida pelo viés afirmativo, a crença de que o canto poderá amparar outro sujeito; mas não se exclui o viés da impossibilidade, pois se trata de uma voz lançada ao mar e que corre, portanto, o risco de ficar à deriva. $\mathrm{O}$ poema termina na suspensão dessas duas alternativas, permanecendo a flagrante desorientação do sujeito, até esta altura apresentado como um malogrado Orfeu, um aedo desamparado.

Os poemas quarto, quinto e sexto formam uma tríade desse desamparo, em que esvanecesse qualquer possibilidade de confiança. A abertura do quarto poema - "Veo los álamos" - replica a cena da composição de Antonio Machado que serve de epígrafe a "De los álamos y los sauces". Lá, o eu-lírico voltava a ver os álamos, que eram dotados da capacidade de conservar as marcas do amor e a música dos rouxinóis e do vento. Os álamos vistos por Alberti, entretanto, têm a implacabilidade do presente e não preservam traço algum da felicidade passada, somente a permanência de todos os mortos. Essa morte onipresente contamina todos os componentes 
dos álamos: sua sombra é de luto; as folhas, de sangue; o movimento de ir e vir - tão característico da leveza dessas árvores - torna-se unidirecional, pois é impossível que as vidas perdidas voltem. Na terceira estrofe, os álamos representam o próprio sentimento do eu-lírico: fatigados e consumidos pela angústia, são a expressão daquele que chora a dor de muitas mortes: "Negros álamos transidos./ ¿Que oscuro caer de amigos!" (ALBERTI, 2003, p. 372).

A interjeição " $i A y$ !" inicia o último verso: " $i A y$, álamos de la muerte!". Forma gráfica tradicional do sentimento doloroso - tanto na tragédia clássica como no grito que precede o cante jondo de extrato popular é índice de que o pranto reclamado no primeiro poema está em curso aqui. O ritmo impresso aos versos pelas orações breves e coordenadas revela um discurso que não consegue fluir, entrecortado talvez pelo soluço daquele que chora. O pranto parece continuar no poema seguinte, o quinto, já que "se oyen caer en estas soledades [...] perdidas claridades" (ALBERTI, 2003, p. 373). O dêitico - estas - além de localizar a solidão como algo próximo do sujeito, também aponta para a materialidade do poema, como uma espécie de denominação de gênero, pois evoca o título que Antonio Machado havia dado a uma de suas obras. Nas Soledades (1889-1907) machadianas, o eu-lírico invariavelmente aparece caminhando só e, por vezes, interpretando o que vê em consonância com seus sentimentos: "Yo iba haciendo mi camino,/ absorto en el solitario crepúsculo campesino" (2012, p.41). A diferença fundamental é que "en estas soledades" albertianas a condição solitária não é uma escolha como em Machado. A morte e o passado perdido que povoam o quinto poema de "De los álamos y los sauces" são mais amargas, uma vez que decorrem da guerra e da violência institucionalizada por um estado ditatorial. Por isso, o som das "perdidas claridades" se adensa com a presença do mar, os céus são belígeros e a luz trazida pelo advento do dia é incapaz de edulcorar a paisagem. Neste cenário, "hasta las tumbas fallecieron" (ALBERTI, 2003, p. 373), nada nasce do solo onde jazem os que se foram, nem o mais ínfimo vegetal.

A partir dessa aproximação que o poema promove entre morte, memória e nascimento de uma planta, é possível estabelecer algumas relações. Primeiro com o álamo, pois em dois relatos mitológicos gregos relaciona-se à memória dos mortos. Os álamos brancos são o resultado da conversão das Helíades, que choram a morte do irmão Fáeton, fulminado por Zeus. Na história de amor do deus Hades pela ninfa Leuce, o álamo é a árvore plantada pelo deus à entrada dos Campos Elíseos para recordar a amada morta (HERRERO UCEDA, 2005, p. 89).

Na poesia moderna, por exemplo, encontramos em Walt Whitman a imagem da planta que brota de uma tumba como sinal de uma nova vida: "The smallest sprout shows there is really no death [...]" $(2014, \text { p. 52) })^{5}$. No poema de Antonio Machado "A un olmo seco", de Campos de Castilla, algumas folhas verdes nascem na velha árvore quase podre partida ao meio por um raio. Essa forma de renascimento da vida que está no mito grego, em Walt Whitman e em Machado não é uma possibilidade para o sujeito lírico albertiano.

Diante desse cenário negativo, que impõe a precariedade da memória, o eu-lírico convoca os "claros extintos", aqueles pelos quais as lágrimas caíam, a achegar-se e dormir na alameda. Para Alberti, a alameda não é só um caminho rodeado por álamos; ela é a espacialização da memória ou a representação de uma memória especializada. Na Arboleda Perdida, por exemplo, a respeito do processo de escritura da obra, Alberti exclama: "Oh complicados senderos de la memoria, hojas lentas que caen llevando cada una escrita, entre sus nervuras, viejas y nuevas sombras que conocí [...]" (2009, p. 593-595).

No poema, o eu lírico argumenta que a alameda, como figuração da memória, é um espaço onde o sonho ainda é possível. Não é por acaso que Alberti retoma essa relação, já que o entrecruzamento de memória, espacialidade e sonho é muito frequente na poesia de Antonio Machado, para quem o lembrar e o sonhar se confundem e se mesclam. Nesse sentido, é paradigmático o poema LXXXIX, da obra machadiana Galerías: " $Y$ podrás conocerte, recordando/ del pasado soñar los turbios lienzos [...]// De toda la memoria, sólo vale/ el don preclaro de evocar los sueños" (2102, p. 106).

Nesses versos, concebem-se o sonho e a memória como formas de conhecimento de si, do passado e do presente. A dimensão sonhadora da memória é entendida como elemento constitutivo, e não desabonador. A beleza do exercício memorialístico de conhecimento reside precisamente no fato de que a memória não corresponde integralmente ao vivido, mas passa por sua elaboração imagética $^{6}$. Essa dimensão criativa, por assim dizer, da memória é o que parece aproximá-la do ofício do poeta, o que não equivale a dizer que o poeta que imagina está necessariamente exercendo um trabalho de memória ${ }^{7}$.

Em "De los álamos y los sauces", notamos a existência de um exercício de retorno ao passado - uma

\footnotetext{
O menor broto mostra que a morte na verdade não existe". Tradução de Rodrigo Garcia Lopes para o poema de Leaves of Grass, citada na bibliografia.

6 A propósito, Paul Ricoeur investiga as relações entre lembrança e imagem e admite a dimensão imaginativa como elemento que constitui o estatuto veritativo da memória (2007, p.61-70).

7 "Imaginar não é lembrar-se. Certamente, uma lembrança, à medida que se atualiza, provavelmente tende a viver numa imagem; mas a recíproca não é verdadeira, e a imagem pura e simples não me reportará ao passado a menos que seja efetivamente no passado que eu vá buscá-la [...]' (BERGSON, 1999, p. 158).
} 
busca - que vai se configurando paulatinamente como um compromisso, dado que o subtítulo da seção já anunciava: os quatorze poemas do conjunto são "En recuerdo de Antonio Machado". Nesse caminho, as imagens de álamos e sauces constituem-se como lembranças na medida em que é por eles, com eles e através deles que o eu-lírico estabelece conexão com o passado, ativa e mobiliza relações que vão erigindo uma memória para Machado.

Entretanto, o processo é penoso, razão pela qual a atmosfera de desamparo das composições anteriores retorna no sexto poema, ainda que este se abra com a reafirmação do compromisso:

\section{Sali a ver los álamos. \\ La tierra huía, temblando. \\ Descoyuntada, la tierra. \\ Sólo vi huesos \\ desparramados. \\ Como vosotros ausentes, álamos? \\ Se oía \\ mudar de forma al planeta. \\ Desprenderse \\ de su arrugada corteza, \\ amarillenta \\ de pobladores ya muertos.}

Álamos,
cómo vosotros risueños?

La sombra, siempre la sombra cedió las llaves al fuego.

Triste desgracia es quemarse

cuando propagan los ríos

su horror ardiendo a los mares.

Sali a ver los álamos.

(Nadie)

(ALBERTI, 2003, p. 374).

O primeiro verso evoca novamente o poema de Machado (He vuelto a ver los álamos...), além de reafirmar um propósito: o sujeito sai em busca da lembrança. Mas o caminho percorrido até ela obriga-o à revisitação de todo o cenário de horror da Guerra Civil Espanhola e de seus desdobramentos, por isso a paisagem descrita pelo eu-lírico é apocalíptica. Entre as estrofes que descrevem o cenário, interpõem-se as perguntas do sujeito, que não consegue compreender a indiferença dos álamos diante da catástrofe: “¿Cómo vosotros ausentes,/álamos?”. O questionamento, misto de angústia e indignação, traz de volta a constatação da impossibilidade do poder órfico do poeta em circunstâncias como a que o sujeito viveu e ainda vive.

A harmonia reinante no ambiente descrito por Antonio Machado, em que os álamos acompanhavam o som das águas e dos pássaros, não existe no poema de Alberti a não ser como uma ausência que a forma denuncia. Isso porque a composição albertiana do sexto poema tenta ser harmônica em sua construção simétrica e reiterativa. Ao contrário da expectativa, no entanto, o poema não termina com a repetição do primeiro verso, "Salí a ver los álamos". Se assim fosse, poderíamos dizer que se vislumbraria um novo início, mas o último verso afirma peremptoriamente: "(Nadie)". A harmonia buscada na forma é, portanto, quase conseguida, pois se dissolve com esse último verso, já que ele não permite que a totalidade se alcance. $\mathrm{O}$ nadie escrito entre parênteses é como a materialização da debilidade do poeta: é só uma meia-voz (um sussurro ou um grito abafado?). Por fim, a forma quase harmônica do poema cria um forte contraste com o conteúdo dos versos: enquanto as palavras dizem a violência, a forma resiste como uma tentativa de controle, último campo em que o poeta pode agir, mas que se revela também contaminada pela impossibilidade circundante.

\subsection{0 melancólico que reflete}

Depois do enfrentamento com as cenas recordadas no sexto poema, observamos que entre a sétima e a décima segunda composições se configura outro movimento em "De los álamos y los sauces". O estado melancólico em que havíamos encontrado o eu-lírico permanece, mas, nesse outro momento, há um sujeito meditativo, como evidencia o verso que se repete três vezes no oitavo poema: “-Estoy pensando" (ALBERTI, 2003, p.376). É precisamente como resultado de um labor reflexivo que o sujeito logrará estabelecer outra relação com a natureza, superando a ideia de que ela ignoraria seu sofrimento. Isso se elabora no sétimo poema.

Depois de "horas y horas" de observação dos álamos e sauces, o sujeito chega a compreendê-los, pois a crise de sua relação com a natureza indiferente obriga-o a rever a condição de ambos. Nesse processo, ele reconsidera a questão do poder órfico do poeta e compreende que não se tratava de indiferença da natureza aos seus sentimentos, mas de uma demanda dos tempos que agora exigem dele um processo racional de reflexão ao contemplar essas árvores. Observando-as ele entende a persistência desses seres: "Fieles, /siempre a la misma altura,/ siempre en la misma grada/del cielo/y con la misma delgadez de airel y el mismo fijo pensamiento" (ALBERTI, 2003, p.375). Sendo tudo o que são e carregando tudo o que carregam - lembramos a densa simbologia de álamos e sauces nas culturas ocidentais: a tristeza, a morte, o pranto, o renascimento, a memória - as árvores conservam-se essencialmente iguais naquilo que as constitui: a altura e a delgadeza que as tornam suscetíveis à passagem do vento. A terceira característica atribuída às árvores, no 
entanto, obriga-nos a reconsiderar que não é só a elas que a persistência se refere. O "fijo pensamento" cria uma identificação entre álamos, sauces e sujeito lírico, afinal é ele quem luta - e está padecendo - em nome da fidelidade às suas ideias. A altura e a delgadeza revelamse então atributos aos quais ele aspira, pois lhe permitirão cantar, como fazem os álamos e sauces movidos pelo vento, ao mesmo tempo em que indicam o desejo de desfazer a postura inclinada. No nono poema, esse anseio é enunciado: "No quiero frente inclinada./ Cabeza alta, / mirada alta, bien alta" (ALBERTI, 2003, p.377).

No entanto, o sujeito fragilizado precisa pedir aos álamos e sauces: "Dadme la mano, amigos, / en el mal tiempo" (ALBERTI, 2003, p. 375). Ainda ouviremos seu grito doloroso ao perceber que toda a simbologia de morte desses mesmos álamos e sauces o envolve como uma mortalha: "¡Ay sauces, me amortajaba!” (2003, p. 377). Nesse percurso intranquilo, há duas questões das quais o sujeito não pode se desviar: seu alheamento e sua relação com a linguagem. No décimo poema, enfrenta-se com a primeira:

Anda serio ese hombre, anda por dentro.

Entra callado.

Sale.

Si remueve las hojas con la tierra, si equivoca los troncos de los árboles, si no responde ni al calor ni al frío y si le ve pararse como olvidado de que está en la vida, dejadle.

Está en la vida de sus muertos, lejos, y los oye en el aire

(ALBERTI, 2003, p. 378).

Por um lado, figura-se no poema um alheamento que corresponde ao exílio - daí seu viés autobiográfico. Lido nesse sentido, a seriedade, o ensimesmamento, as poucas palavras do sujeito e sua desorientação são a condição do exilado vista por dentro. O exílio aqui é mais que o fenômeno histórico e que a consequência de uma posição ideológica, aspectos que não deixam de estar presentes; mas o exílio é, sobretudo, o dilaceramento da vida de um sujeito. Isso se evidencia no verso "si equivoca los troncos de los árboles", pois na poética de Alberti a percepção da natureza é sempre muito precisa, advinda de sua familiaridade com os elementos naturais. Na Arboleda Perdida, por exemplo, ele diz com orgulho: "No soy de aquellos poetas [...] que confunden una amapola con una margarita [...]. Yo casi poco después de aprender a leer conocía ya, identificándolos con la realidad, muchos nombres de flores, árboles y plantas" (2009, p. 383). Para alguém com este tipo de proximidade com a natureza, a dificuldade de diferenciar os troncos das árvores é muito significativa. Trata-se mesmo de um sintoma do que é viver a experiência desorientadora do exílio.

Por outro lado, o alheamento do sujeito também é uma posição reivindicada, como indica o verbo "dejadle" (lembremos o "dejadme" do primeiro poema do conjunto). Desse modo, a seriedade, o ensimesmamento e as poucas palavras se devem ao fato de que o sujeito está dedicado à memória dos seus mortos, o que permite entrever que um fenômeno mais complexo está se dando: o luto ${ }^{8}$. E para um poeta, esse processo de elaboração não pode ser feito sem uma reflexão sobre a linguagem, uma vez que ela é seu meio de expressão. Esse enfrentamento, Rafael Alberti fará no décimo primeiro poema:

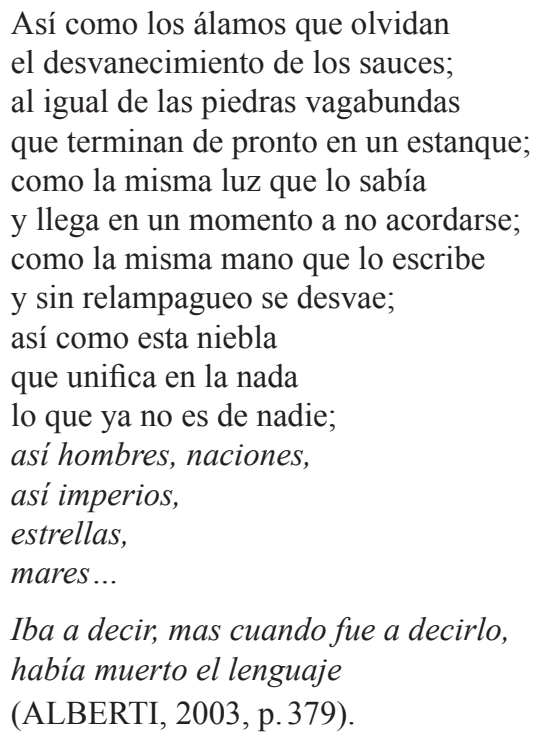

Iba a decir, mas cuando fue a decirlo, habia muerto el lenguaje

(ALBERTI, 2003, p. 379).

Em todos os níveis de análise que o consideremos, verifica-se que se trata de um poema da desintegração. No aspecto formal, como bem observa López Martínez (2002), a disposição dos versos no branco da página, cujos números de sílabas poéticas vão decrescendo, representa graficamente a dissolução.

No nível conteudístico, todos os elementos estão igualmente desintegrados: os álamos se esquecem; os sauces desvanecem; as pedras estão estancadas; a luz somase ao obscuro esquecimento; e a própria mão daquele que escreve se esvai. Constrói-se uma acumulação às avessas, pois quanto mais se enumera, mais a dissolução avança. A névoa (esta niebla/ que unifica en la nada) conforma-se como a grande imagem que domina o poema, tornando tudo indistinto sob sua superfície espessa e branca.

Na segunda estrofe, a dissolução atinge também a linguagem: o sujeito é indefinido e não se sabe o que ele quer dizer. A morte da linguagem é a constatação da

\footnotetext{
8 Embora conheçamos as reflexões de Freud sobre o luto no clássico ensaio "Luto e melancolia" (1915-1917), decidimos não o incluir aqui, pois a relação exigiria uma reflexão que excederia os limites do artigo.
} 
impossibilidade de nomear a experiência. Rafael Alberti parece chegar aqui à consciência da irrepresentabilidade do que, àquela altura, eram os primeiros episódios que conformariam a terrível face do século XX. A crise da representação diante da barbárie - "a quebra de confiança, da fluência na relação entre o homem e as formas familiares de expressão", na análise de Valeria De Marco (2004, p. 53) - torna-se também para ele um problema ético e estético.

Tendo meditado sobre essas questões, o que não significa que as soluciona ou supera, o eu-lírico melancólico encontra-se com outra disposição no décimo segundo poema:

\author{
Ahora me siento ligero, \\ como vosotros, ahora \\ que estoy cargado de muertos. \\ Voy a crecer, a subir. \\ Voy a escalaros \\ ahora que tengo mil años. \\ ¡Detenedme, que ya subo! \\ ¡Paradme, que ya os alcanzo! \\ ¡No me dejéis, ya en el viento, \\ mirar abajo \\ (ALBERTI, 2003, p. 380).
}

Logo na abertura do poema, estabelece-se um diálogo com Antonio Machado, especificamente com o "Retrato", primeira composição de Campos de Castilla, em cuja última estrofe se lê: "Y cuando llegue el día del último viaje, /y esté al partir la nave que nunca ha de tornar, / me encontraréis a bordo, ligero de equipaje, / casi desnudo, como los hijos de la mar" (2012, p.113). Os versos revelam um eu-lírico que tem uma consciência serena da própria mortalidade. A expressão "ligero de equipaje" é consoante à vida de um homem que assumiu "éticamente la existencia", como comenta Díaz Arenas (2000, p. 114) ao analisar "Retrato".

Essa leveza de bagagem ganha em Alberti outra configuração: o sujeito consegue sentir-se "ligero" agora que está "cargado de muertos", ou seja, trazer consigo a lembrança dos mortos é a sua maneira de alcançar a leveza. Aquele processo de luto parece consumar-se, pois o eu-lírico, que antes estava distante (en la vida de sus muertos), agora leva os mortos consigo. E é na memória que esses mortos habitam, tal como sugere o verso "ahora que tengo mil años", em que ressoa a abertura do segundo "Spleen" de Charles Baudelaire: "J'ai plus de souvernirs que si j'avais mille ans" (2012, p.282), estabelecendo uma relação em que ter mil anos é ter muitas lembranças.

A chegada a este estado não significa o apaziguamento da tristeza. Com efeito, permanece a nota dissonante. Primeiro, pelo contraste entre o que significava a leveza de bagagem em Antonio Machado e a natureza da carga que o eu-lírico albertiano precisa levar para admitir-se leve. Ademais, a evocação de Baudelaire traz novamente o traço da melancolia 9 .

É com a lucidez da complexidade de seu compromisso com a memória, que o eu-lírico anuncia seu ímpeto também baudelairiano - de ir para o alto. O movimento em direção à sublime poesia (¡Detenedme, que ya subo!) não é, contudo, ingênuo. É uma aspiração que se declara sem deixar de pontuar o dado da vertigem: o medo, a consciência da crise, a impossibilidade.

\section{Para Antonio Machado, o poeta enterrado em outra terra}

O último poema de "De los álamos y los sauces" é aquele declaradamente escrito para Antonio Machado. " $A$ ti, enterrado en otra tierra" diz a dedicatória que o precede e estabelece uma identificação entre o poeta e Rafael Alberti pelo jogo com as palavras "terra" e "enterrado", que não deixam de ecoar a condição deste que escreve: o desterrado. Todo o poema é construído a partir do motivo que a dedicatória cria. Antonio Machado é realmente o poeta que foi enterrado fora da Espanha. Morre em 22 de fevereiro de 1939, depois de ter atravessado a fronteira com a França ao final da Guerra Civil Espanhola e é enterrado em Colliure.

O poema é, significativamente, o mais longo do conjunto, composto de quatro estrofes de oito versos cada, sem padrão de metro ou rima. Os versos, em geral, longos, os encavalgamentos que se sucedem e as orações extensas são características que lhe conferem um ritmo de fala desabalada, como se atendesse a uma necessidade que agora finalmente se desata. Nota-se uma marcação rítmica ancorada nas repetições de "Pienso en ti" e "Descansa" a partir da segunda estrofe, quando efetivamente tudo o que se queria dizer a Antonio Machado é dito: “[...] pienso en $t i$, en esa noble osamenta abonando trigos merecedores de más verdes alturas [...]// Pienso en ti, grave, umbrio, el más hondo rumor que resonara a cumbre [...]" (ALBERTI, 2003, p. 382).

A abertura do poema é como um preâmbulo da homenagem, pois o sujeito nos diz em que circunstâncias renova seu compromisso com a memória. Trata-se de um cenário bastante adverso em que reaparece a interjeição dolorosa (Perdidos, ;ay, perdidos!), e todos os elementos estão imersos numa atmosfera mórbida e sem esperança: as crianças por cidades estilhaçadas, as auroras lentas que têm sabor a mortos, os cachorros sem dono que ladram diante de ruínas... No próprio Machado encontramos

\footnotetext{
9 Lembremos o significado de spleen: "[...] proveniente do inglês, que o formara a partir do grego (splên, o baço, sede da bile negra e, portanto, da melancolia) [...]" (STAROBINSKI, 2014, p. 16).
} 
imagens semelhantes: no poema LXXVII de Galerías: o cachorro esquecido que erra pelos caminhos, o menino perdido na multidão, o poeta que se iguala ao bêbado melancólico e ao guitarrista lunático (2012, p.98-99); e em CVI de Campos de Castilla: o louco sozinho que vocifera com sua sombra e sua quimera (2012, p. 130). Também na sombria obra Sobre los ángeles (1929) de Alberti deparamo-nos com atmosfera análoga.

Esse cenário de devastação e desencanto que era o passado - sobreposição da memória literária, artística e histórica do poeta - se converte em um presente na passagem para a segunda estrofe: "entonces, que es ahora,/pienso en ti" (2003, p. 382). A partir deste verso, em que se ouve novamente o eco de Baudelaire ${ }^{10}$, o eu-lírico reitera seu compromisso com a memória do outro, devotando a ele seu exercício de meditação. Nesse pensar, o sujeito imagina para Antonio Machado uma paisagem que em tudo se assemelha àquelas que povoam os poemas de Campos de Castilla: a fertilidade da terra, o canto das árvores, o crepúsculo vespertino. O que foi impossibilidade de renascimento ao longo de "De los álamos y los sauces" encontra outra forma de brotar: Antonio Machado se converte em semente. O eu-lírico devota ao poeta morto mais do que o seu pensamento e a sua imaginação, entrega-lhe o próprio espaço do poema, e é assim que nos versos de Rafael Alberti a poética de Antonio Machado volta a existir. Cumpre-se a assertiva do vigésimo oitavo verso: "sobre difuntos bosques va el campo venidero" (2003, p.383).

$\mathrm{Na}$ última estrofe, o poeta reafirma, localiza e data seu compromisso com o não-esquecimento: "Descansa en paz, soldado/ Siempre tendrá tu sueño la gloria necesaria:/ Álamos españoles hay fuera de Castilla;/ Guadalquivir de cánticos y lágrimas del Duero. //En El Totoral// (Córdoba de América), 1940, junio" (2003, p. 383).

Encerra "De los álamos y los sauce" o verso com o qual Federico García Lorca arremata "Cuerpo presente", terceiro poema de seu Llanto por Ignacio Sánchez Mejías. "Duerme, vuela, reposa: ¡También se muere el mar!" (GARCÍA LORCA, 1954, p.470), um desdobramento lírico do epitáfio comum, Requiescat in pace, é a expressão que o sujeito pode alcançar depois de ter aprendido a chorar pela morte de um amigo. Ao longo de "De los álamos y los sauces", Rafael Alberti também parece ter buscado esse aprendizado (no que nessa palavra há de dor, processo e trabalho). Termina não com uma resposta, mas com o vislumbre de caminho, um caminho que será talhado pela poesia.

\footnotetext{
10 "Andromaque, je pense à vous!" (2012, p.312) abre o célebre poema "O cisne".
}

\section{Considerações finais}

A leitura detida dos poemas de "De los álamos y los sauces" demonstra que no primeiro momento do exílio, um ano após o fim da Guerra Civil Espanhola, um grande signo da poética de Rafael Alberti é a desorientação. Isso se revelou nas tentativas de busca na tradição literária por referências para o seu próprio canto, para a relação entre sujeito e natureza e para o trabalho da memória. Ao longo desse percurso árduo, o eu-lírico que habita os poemas de "De los álamos y los sauces" vê sucessivamente corrompidas as certezas que sustentavam o imaginário da literatura ocidental. Nem Orfeu, nem o aedo, nem a natureza receptiva, nem o locus amoenus, nem a memória bem-sucedida são possíveis em tempos em que a barbárie é o procedimento padrão dos Estados Nacionais, tempos em que o poeta morre porque toca a sua lira. É certo que os grandes topos da literatura Antiga muito antes desses anos de 1940 já haviam sofrido um processo de corrosão, e Alberti não ignora isso. No entanto, as certezas que vão se revelando como impossibilidades são o modo que ele encontra para figurar a condição do poeta no imediato pós-Guerra Civil Espanhola. Essa é a questão central em "De los álamos y los sauces". Um conjunto de poemas feito para um poeta, que convoca uma série de referências e dispara uma gama de relações externas justamente para dizer da desorientação e do desamparo que cala no mais íntimo desse sujeito. Assim, "De los álamos y los sauces" não nomeia a desorientação, como acontece no texto de 1987 que lembra o mesmo momento, mas a figura poeticamente.

Em 1940, Rafael Alberti ainda não pode saber que realmente fará de toda sua poesia um compromisso à memória da sua Espanha. Entre el clavel y la espada é um grande ponto de inflexão neste caminho, pois é o momento do dilaceramento recente, da tomada de decisão por uma ética e por uma estética.

\section{Referências}

ALBERTI, Rafael. La voz de Rafael Alberti. Leitura gravada em 10 de novembro de 1988. Madrid: Publicaciones de la Residencia de Estudiantes, 1999.

ALBERTI, Rafael. Poesía II. Ed. Robert Marrast. Barcelona: Seix Barral, 2003.

ALBERTI, Rafael. Poesía III. Ed. Jaime Siles. Barcelona: Seix Barral, 2006.

ALBERTI, Rafael. Prosa II. Memorias. La arboleda perdida. Ed. Robert Marrast. Barcelona: Seix Barral, 2009.

BAUDELAIRE, Charles. As Flores do Mal. Trad. Ivan Junqueira. Rio de Janeiro: Nova Fronteira, 2012.

BENJAMIN, Walter. Origem do drama barroco alemão. São Paulo: Brasiliense, 1984. 
BERGSON, Henri. Matéria e memória. Estudo sobre a relação do corpo com o espírito. Trad. Paulo Neves. São Paulo: Martins Fontes, 1999.

CARMO NETO, Júlio Maria do. Metamorfoses X, o livro de Orfeu: introdução tradução e notas. Dissertação (Mestrado) Universidade Estadual de Campinas. Instituto de Estudos da Linguagem. Campinas, 2009.

CHEVALIER, Jean. Diccionario de símbolos. Barcelona: Herder, 1986.

DE LA VEGA, Garcilaso. Obra poética. Edición de Bienvenido Morros. Madrid: Crítica, 1995. Disponível em: <http://www. rae.es/sites/default/files/Obra_poetica_Garcilaso_de_la_Vega. pdf $>$. Acesso em: 27 jul. 2015.

DÍAZ ARENAS, Ángel. Evolución poética de Jaime Siles. Kassel: Reichenberger, 2000.

GARCÍA LORCA, Federico. Llanto por Ignacio Sánchez Mejías. In: GARCÍA LORCA, Federico. Obras completas. Madrid: Aguilar, 1954. p. 461-471.

HADOT, Pierre. The veil of Isis. An essay on the history of the idea of Nature. Trad. Michael Chase. Massachusetts: Harvard University Press, 2006.

HERRERO UCEDA, Miguel. El alma de los árboles. Madrid: Hedras, 2005.

Lírica española de tipo popular. Edición de Margit Frenk. Madrid: Catedra, 2010.
LÓPEZ MARTÍNEZ, María Isabel. Ritmo visual y compromiso en poemas de Rafael Albert. Anuario de estudios filológicos. Vol. XXV, 2002, p. 237-251. Disponível em: <http://dialnet. unirioja.es/descarga/articulo/298601.pdf $>$. Acesso em: 28 jun. 2015.

MACHADO, Antonio. Poesía. Buenos Aires: Losada, 2012.

MARCO, Valeria de. A literatura de testemunho e a violência de estado. Lua Nova, n. 62, 2004, p. 44-68. Disponível em: <http:// www.redalyc.org/articulo.oa? $\mathrm{id}=67312435004>$. Acesso em: 30 mar. 2015.

RICOEUR, Paul. A memória, a história, o esquecimento. Trad. Alais François et al. Campinas: Editora da Unicamp, 2007.

STAROBINSKI, Jean. A melancolia diante do espelho. Trad. Samuel Titan Jr. São Paulo: Editora 34, 2014.

SONTAG, Susan. Sob o signo de Saturno. In: SONTAG, Susan. Sob o signo de Saturno. Trad. Ana Maria Capovilla e Albino Poli Jr. São Paulo: L\&PM, 1986. p. 85-103.

WHITMAN, Walt. Folhas de Relva. Tradução e posfácio de Rodrigo Garcia Lopes. São Paulo: Iluminuras, 2005.

Recebido: $21 / 01 / 2016$

Aprovado: 29/01/2016

Contato: mayramoreyra@gmail.com 